\title{
Semantic Songket Image Search with Cultural Computing of Symbolic Meaning Extraction and Analytical Aggregation of Color and Shape Features
}

\author{
Desi Amirullah, Ali Ridho Barakbah, Achmad Basuki \\ Electronics Engineering Polytechnic Institute of Surabaya \\ Jl. Raya ITS - Kampus ITS Sukolilo Surabaya 60111, Indonesia \\ Telp : 62315947280 Fax : 62315946114 \\ Email : ${ }^{1}$ andes.st@gmail.com, ${ }^{2}$ ridho@pens.ac.id, 3basuki@pens.ac.id
}

\begin{abstract}
The term "Songket" comes from the Malay word "Sungkit", which means "to hook" or "to gouge". Every motifs names and variations was derived from plants and animals as source of inspiration to create many patterns of songket. Each of songket patterns have a philosophy in form of rhyme that refers to the nature of the sources of songket patterns and that philosophy reflects to the beliefs and values of Malay culture. In this research, we propose a system to facilitate an understanding of songket and the philosophy as a way to conserve Songket culture. We propose a system which is able to collect information in image songket motif variations based on feature extraction methods. On each image songket motif variations, we extracted philosophy of rhyme into impressions, and extracting color features of songket images using a histogram 3D-Color Vector quantization (3D-CVQ), shape feature extraction songket image using HU Moment invariants. Then, we created an image search based on impressions, and impressions search based on image. We use techniques of search based on color, shape and aggregation (combination of colors and shapes). The experiment using impression as query : 1) Result based on color, the average value of true 7.3 , total score $41.9,2$ ) Result based on shape, the average value of true 3 , total score $16.4,3$ ) Result based on aggregation, the average value of true 3 , total score 17.4. While based using Image Query : 1) Result based on color, the average precision 95\%, 2) Result based on shape, average precision 43.3\%, 3) Based aggregation, the average precision $73.3 \%$. From our experiments, it can be concluded that the best search system using query impression and query image is based on the color.
\end{abstract}

Keyword : Image Search, Philosophy, impression, Songket, cultural computing, Feature Extraction, Analytical aggregation. 


\section{INTRODUCTION}

The term Songket comes from the Malay word Sungkit, which means "to hook". It has something to do with the methode of songket making : to hook and pick a group of threads, and then slip the gold and silverthreads in it. Every names of songket motifs and variations derived from plants and animals as source of inspiration to create many patterns of songket. Each of songket patterns have a philosophy in form of rhyme that refers to the nature of the sources of songket patterns, philosophy reflects the beliefs and values of Malay culture [7]. Songket is a luxury product traditionally worn during ceremonial occasions like a Malay festival or Malay wedding as sarong, shoulder cloths or head ties and tanjak, a headress songket. While for women draping at the shoulder, but over the times songket motifs are also used in the clothing brackets, and etc. Songket motifs are contained 142 patterns, and each of patterns has a philosophy in the rhyme[1].

Unlimitied advance of information technology makes it easier. But, informations of songket are very limited as cause of the younger generation and the general public is less interested in preservation, especially prospective buyers are less interested in buying and using songket. Because lack of information cultural values contained in songket and that have impact on artisans songket, so that a reduction in industrial production due to low songket market. Information technology has given space of foreign culture without a good selection by the younger generation, so that if it is not accompanied by information about songket, gradually younger generation will leave its own cultural heritage, and future historians will lose track of songket cultural history that have cultural relations with some countries, especially in the Asia region.

\section{RELATED WORKS}

Previous works related to the research that we do on pattern recognition or image search are discussed in this sub-chapter. Research conducted by R. Venkata Ramana Cahry et al[4] on an interactive image search system with Interacted friendly approach, this study focuses on the application of image search in a large amount based on the projected color and mathematical approaches. Ali Ridho Barakbah et al[3] conducted a research for extracting color features using 3D-color vector quantization Histogram of RGB color space, implementation of 3D-CVQ method to describe the similarity between the query image with image database, evaluation in this system uses a collection of images COREL that contained any categories of images. Indah Yudi Suryani et al[8] conducted a research on image search using a multi-query image and displayed the results of an image that is most similar, multi-query models provide function analytical to search that produced representative color features, using a 3-D histogram CVQ for feature extraction of color in the image. Adaptive adjustment of color representation by measuring the density distribution of the color. Experimental using 1000 images with 10 categories. Ayuninda Dwi 
Nugrowati et al[5] conducted a reserach Batik image search system with an analytical function, feature extraction involves color and shape features, for experiment using 210 images of three kinds of batik batik pattern: kawung, Parang, Mega Mendung. Image search system is using an image as the query and displays the images start from the similar.

\section{ORIGINALITY}

This research proposes a new approach of search technique to guide user in searching knowledge about the Songket image and impression based on image or impression query. The process of search based on impressions that displayed the results of images, and process of search based on the image that displayed the results of impressions. The search system is done based on color, shape, and the combination of colors and shapes feature. Feature extraction used to extract impressions, colors and shapes which contained within each image variation songket motifs. The color feature extraction is using histogram 3D-CVQ and shape feature extraction is using $\mathrm{Hu}$ Moments invariant, while for the extraction of the impression, we do research in the field with local cultural leaders about the philosophy in rhymes contained in each of variation songket motifs into impressions easily understood by the public. Feature extraction process to produce 3 metric metadata are impressions feature metric, colors feature metric and shapes feature metric. Then, we do multiplication metric between impression metric and colors metric that produced metric color-impressions, and multiplication metric between impression metric and shapes metric that produced impression-shape metric. Feature extraction process colors and shapes are also performed on the query image.

\section{SYSTEM DESIGN}

Design system describes the steps to be undertaken to achieve the aims of this research. The system design has a collection of images that denote a group of images used in the experiment. Hereinafter, the process of feature extraction in image collection generate impressions, colors and shapes metrics. Then, it carried out the process of multiplication metric that generates impressions-color metric and impressions-shapes metric. In the system to be built, we use images and impressions as a query. In the query image, feature extraction process is carried out to obtain the color and shape feature, and then the similarity measurement process display the results of impressions. Impressions query selected from a list of impressions, based on impressions that selected taken metadata of impression-color metric and impression-shape metric, and then the similarity measurement with color metric and shape metric, and then display the results of images that are similar impression that contained in the images with selected the impression. Design system development to ease of understanding on semantic songket image and impression retrieval system. 


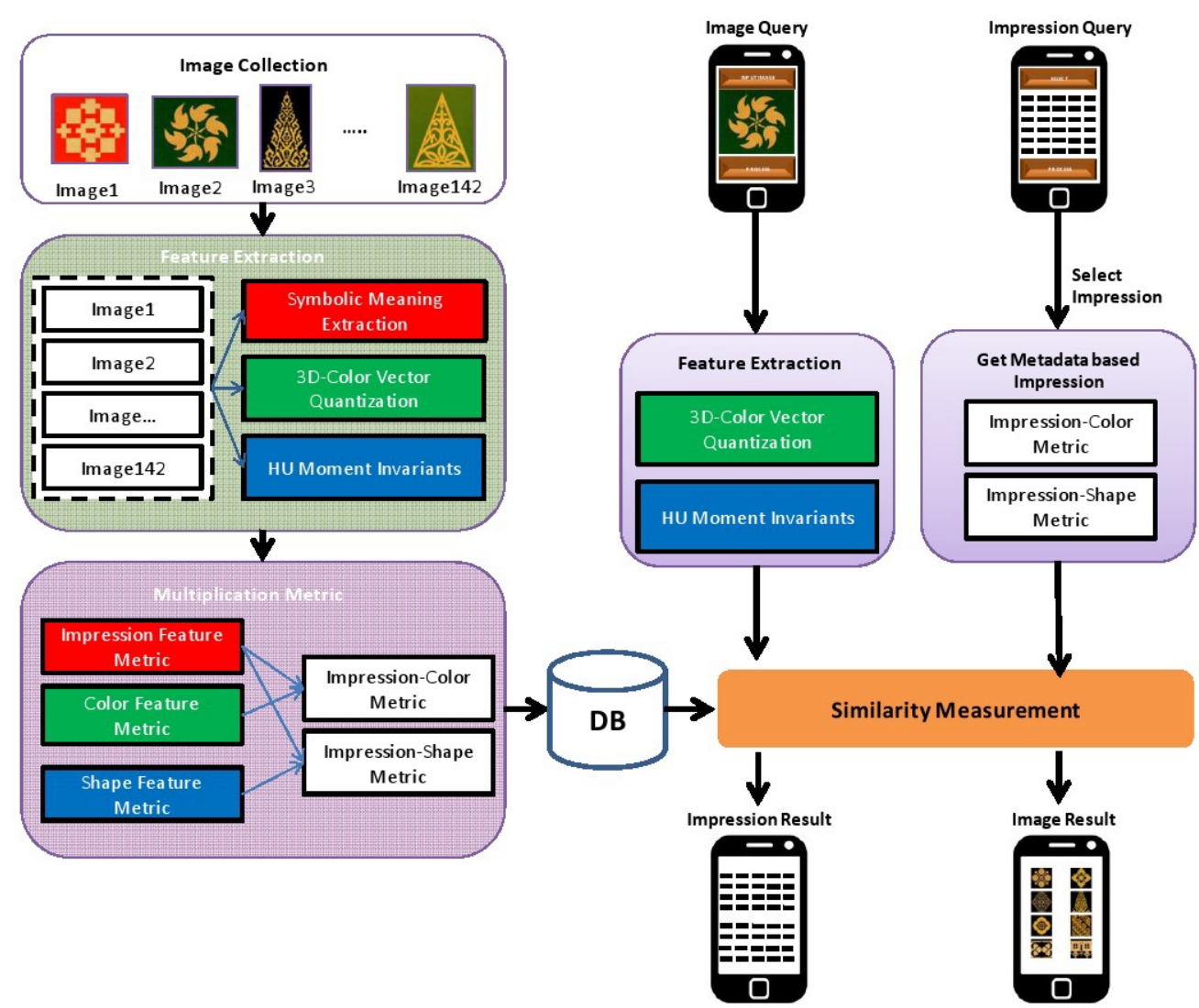

Figure 1. Design System of Semantic Songket Image Search with Cultural Computing of Symbolic Meaning Extraction and Analytical Aggregation of Color and Shape

Features

We use 3D-CVQ method for color feature extraction, it can to reduce a complexity RGB colors in the image and unifies the close colors in the vectors space[3]. Meanwhile, we use $\mathrm{Hu}$ Moment invariants method for the shape feature extraction, because has defined a set of seven moments that are invariant under the actions of translation, scaling, and rotation[9], so that it can provide a good experiment when using the query image from images taken using a smartphone cameras (This system is implemented using a smartphone based on Android operating system). Several steps and the algorithm used to build this system will be discussed in the following sections : image collection, feature extraction, multiplication metric, image/ impression query, similarity measurement.

\subsection{Image Collection}

Songket images that used in this study are grouped of image collections. We used 142 images taken from Riau Malay songket weaving pattern. In each variation songket motifs images containing of philosophy in the different rhyme, in this research be extracted to the impression. 


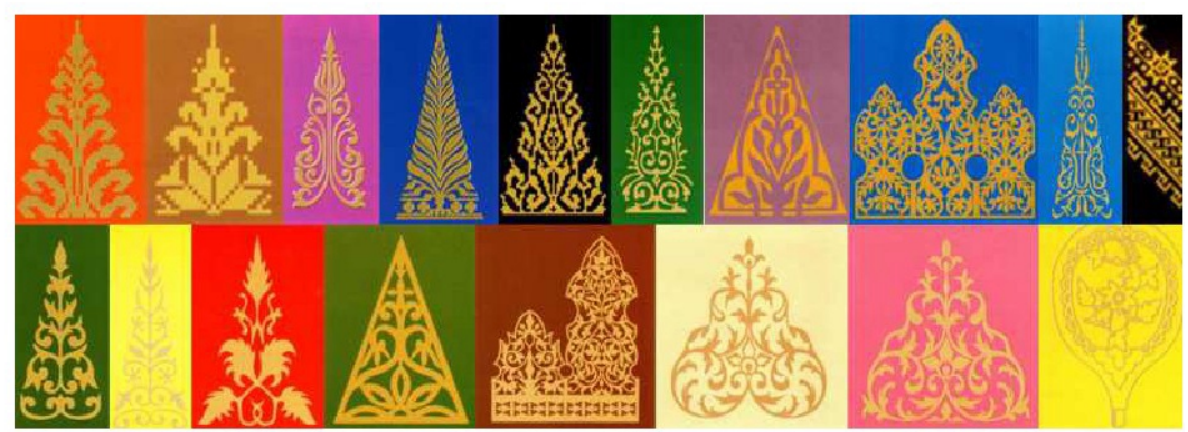

Figure 2. Example Songket Motif Variations of Riau Malay Culture

\subsection{Feature Extraction}

Feature extraction is an extracting features from images collection. This feature extraction produce the metadata impression, color and shape feature metric. Metadata feature metric saved into the database. Figure 3 shows the feature extraction process of image collection.

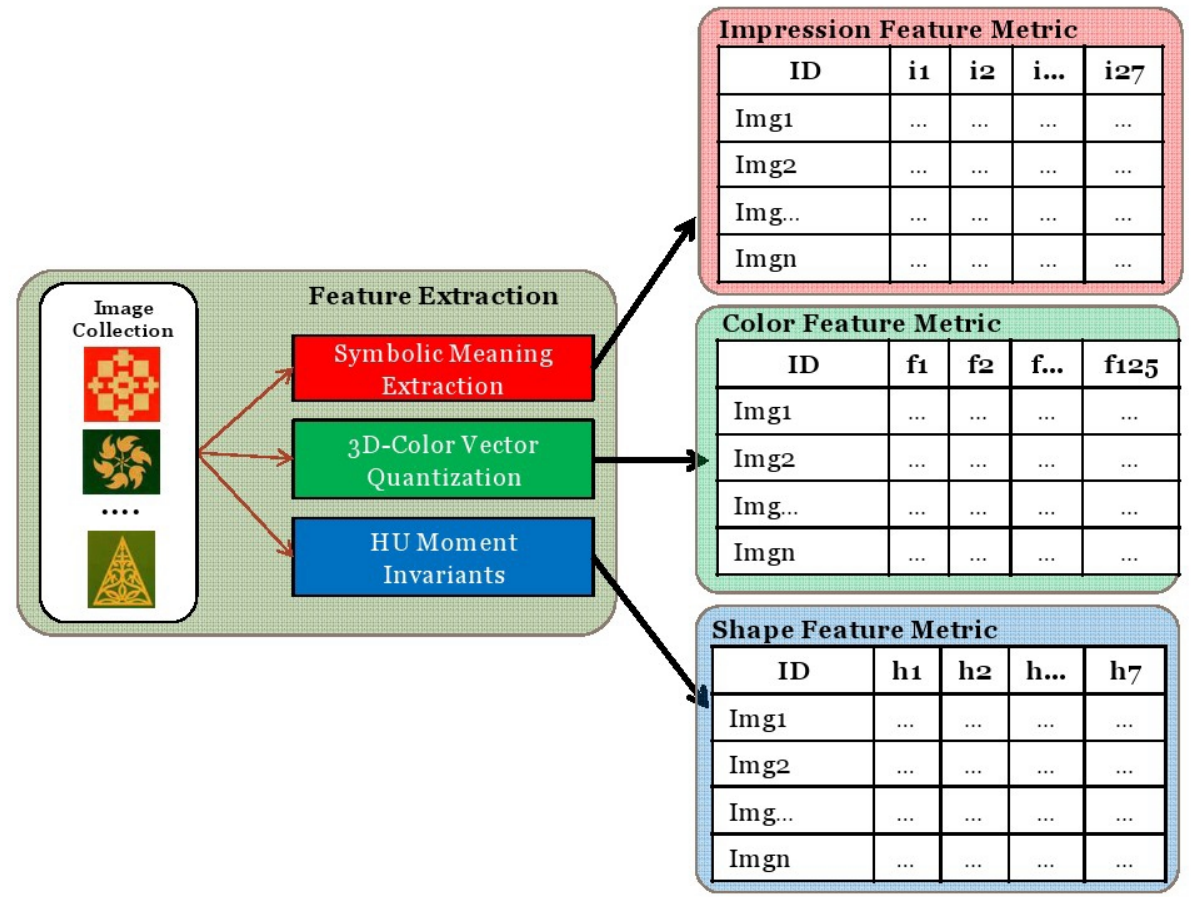

Figure 3. Images Feature Extraction to get impression feature metric, color feature metric, and shape feature metric

Except of images collection, image query given by the user in aplication use the histogram 3D-Color Vector Quantization for extracting color feature, and use the Hu Moment Invariants method for extracting shape feature.

\subsubsection{Symbolic Meaning Extraction}

Each image has more than one impression, impressions taken based on the color meaning and shape variations, songket motifs interpreted in the rhyme by the local cultural leaders. For symbolic meaning extraction that we do research in the field with local cultural leaders about the philosophy of 
rhymes that contained in each of songket motifs into impressions in order to easily understood by the public (figure 4). From 142 images variation songket motifs that we used, we found 27 impressions contained in all the image collection (Table 1).

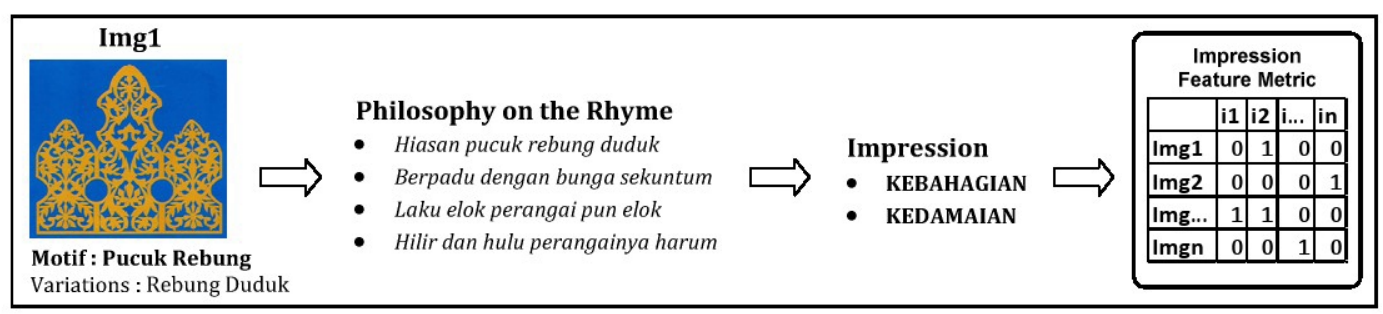

Figure 4. Steps of Symbolic Meaning Extraction

Table 1. List of Impression

\begin{tabular}{|c|l|c|l|}
\hline Code & \multicolumn{1}{|c|}{ Meaning } & Code & \multicolumn{1}{|c|}{ Meaning } \\
\hline S1 & Kesetiaan & S15 & Kerukunan \\
\hline S2 & Keberanian & S16 & Gotong Royong \\
\hline S3 & Kepahlawanan & S17 & Tenggang_Rasa \\
\hline S4 & Kesuburan & S18 & Kasih Sayang \\
\hline S5 & Kemakmuran & S19 & Saling Menghormati \\
\hline S6 & Kesucian & S20 & Ketulusan \\
\hline S7 & Berhati Mulia & S21 & Tahu Diri \\
\hline S8 & Berwibawa & S22 & Amanah \\
\hline S9 & Bangsawan & S23 & Ketaqwaan \\
\hline S10 & Persaudaraan & S24 & Bijaksana \\
\hline S11 & Kebahagian & S25 & Sopan Santun \\
\hline S12 & Kedamaian & S26 & Rendah Hati \\
\hline S13 & Murah Rezeki & S27 & Cerdik Pandai \\
\hline S14 & Kesejahteraan & \multicolumn{3}{|l}{} \\
\cline { 1 - 2 } & \multicolumn{1}{|l}{} \\
\cline { 2 - 3 }
\end{tabular}

From the list of impression in Table 1, and of the 142 Image Collection, it can be made Impression Metric Feature as in Table 2.

Table 2. Table of Impression Feature

\begin{tabular}{|l|c|c|c|c|}
\hline \multicolumn{1}{|c|}{$\boldsymbol{I D}$} & $\boldsymbol{i 1}$ & $\boldsymbol{i 2}$ & $\boldsymbol{i} \ldots$ & $\boldsymbol{i 2 7}$ \\
\hline Imgl & $\ldots$ & $\ldots$ & $\ldots$ & $\ldots$ \\
\hline Img2 & $\ldots$ & $\ldots$ & $\ldots$ & $\ldots$ \\
\hline Img $\ldots$ & $\ldots$ & $\ldots$ & $\ldots$ & $\ldots$ \\
\hline Imgl42 & $\ldots$ & $\ldots$ & $\ldots$ & $\ldots$ \\
\hline
\end{tabular}

\subsubsection{Color Feature Extraction}

We use Histogram of Three Dimensional (3D)-Color Vector Quantization of RGB color space[3] for extraction color feature. From the RGB color space becomes the quantization size $64 \times 64 \times 64$ to 125 position space of RGB [3]. The formula of image quantization as following. 


$$
H_{\mathrm{i}}=\sum_{j=1}^{j=n} H_{j} \quad\left\{\begin{array}{l}
H j=1 \leftarrow \min (\mathrm{D}(R G B j, R G B i) \\
H j=0 \leftarrow \text { otherwise }
\end{array}\right.
$$

Where, $H i$ Histogram of 125 positions in the RGB color space, $H j$ Pixel image, $n$ Number of pixels, $\mathrm{D}(R G B j, R G B i)=$ Distance between the RGB Color pixel $j$ and RGB color position $125[1]$.

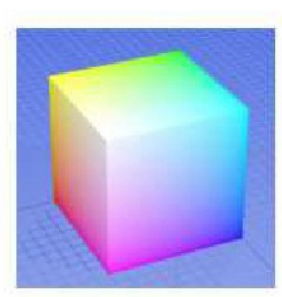

RGB Color Space
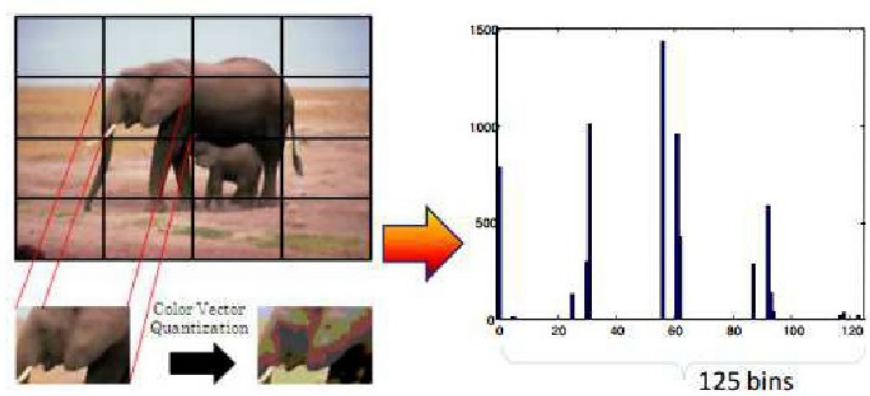

125 bins

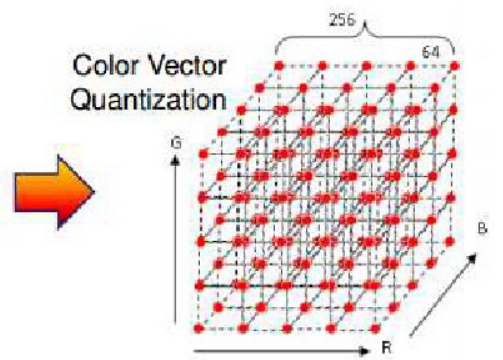

Figure 5. Mechanism of color feature extraction[5] using 3D-Color Vector Quantization

Figure 6 shows the extraction color feature process of songket image collection using 3D-Color Vector Quantization, and produces color feature metric.

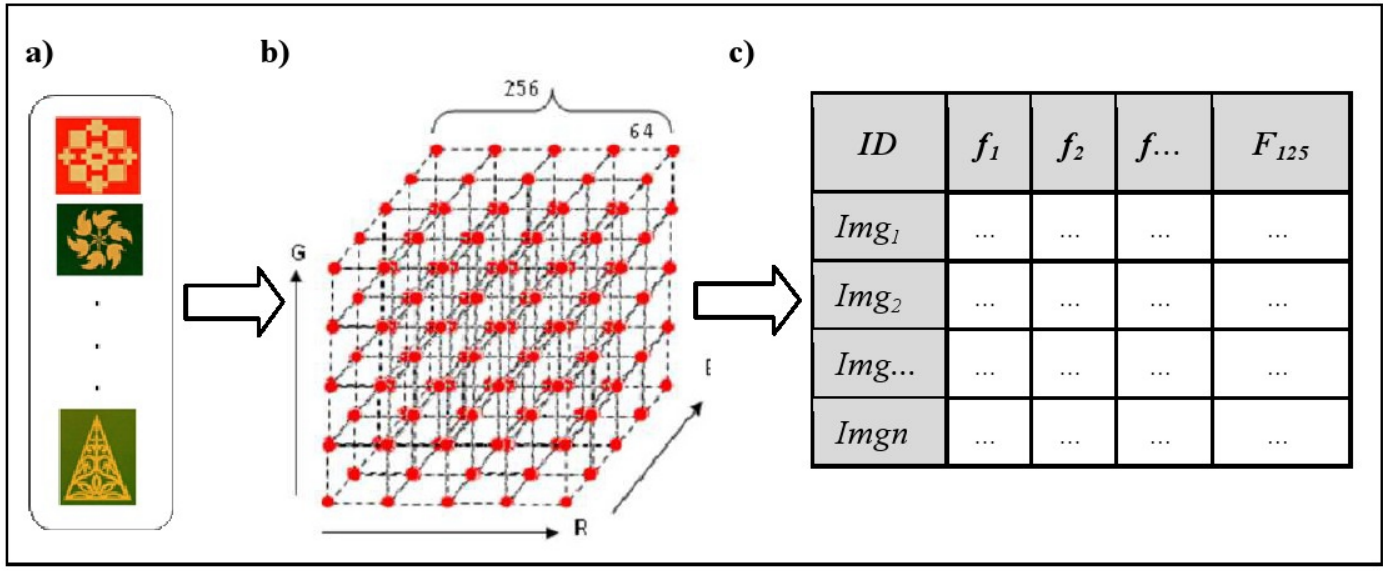

Figure 6. Color feature Extraction : a) Image Collection, b) 3D-Color Vector Quantization form RGB Color Space of image dataset process [3], c) Image Color Feature Metric 
Where, a) Image Collection, motif songket image from Riau which has 142 motifs. b) 3D-Color Vector Quantization of a image collection process, has 125 positions in RGB color space. c) Image color feature metric (f1, f2, f..., f125), $I m g_{1}, I m g_{2}, I m g . . . I m g_{n}$ is a ID of images. Color feature extraction using 3D-CVQ of 142 images collection, and outcome $142 \times 125$ metric color feature (figure 6.c.).

\subsubsection{Shape Feature Extraction}

Shape feature extraction is an process of shape extraction the image songket using the Hu Moments invariant method based on the calculation of moments in the middle of area and produce metadata shape feature metric. $\mathrm{Hu}$ Moment invariant was found by $\mathrm{Hu}$ in 1962 which resulted in seven equations which do not influence the rotation, translation, and scale[6]. The basic equation of the moment an object is defined as follows :

$$
m_{i j}=\sum_{x} \sum_{y} x^{i} y^{j} a_{x y}
$$

Order of the moment is $(i+j), x$ and $y$ stated the coordinates of points, while $\mathbf{a}_{\mathbf{x y}}$ stated intensity point. Moment level 0 and 1 (zero and first-order moments) defined as follows.

$$
\begin{aligned}
& m_{00}=\sum_{x} \sum_{y} a_{x y} \\
& m_{10}=\sum_{x} \sum_{y} x \cdot a_{x y} \\
& m_{01}=\sum_{x} \sum_{y} y \cdot a_{x y}
\end{aligned}
$$

In the binary image $\mathbf{a}_{\mathbf{x y}}$ is worth 0 or 1 , moment moo same the object area. Center or centroid of the area is a parameter to express the location of the object. Central area of the object is defined as follows.

$$
x^{\prime}=\frac{m_{10}}{m_{00}} \text { and } y^{\prime}=\frac{m_{01}}{m_{00}}
$$

Center coordinates of the object is $\left(x^{\prime}, y^{\prime}\right)$ central moment $\boldsymbol{\mu}$ is the moment that corresponds to the central area, is defined as follows.

$$
\mu_{i j}=\sum_{x} \sum_{y}\left(x-x^{\prime}\right)^{i}\left(y-y^{\prime}\right)^{j} a_{x y}
$$

Normalized central moment is expressed by the following equation.

$$
\eta_{i j}=\frac{\mu_{i j}}{\left(\mu_{00}\right)^{\lambda}}
$$

With $\lambda=\frac{(i+j)}{2}+1, \quad$ and $(\mathrm{i}+\mathrm{j}) \geq 2$ (moment the level to- 1 is always in variant). 
From the moment normalized above, a set of Invariant Moment can be defined. These moments are very useful in making a feature vector for object recognition. Below is the equation of Invariant Moment :

$$
\begin{aligned}
\varphi_{1}= & \eta_{20}+\eta_{02} \\
\varphi_{2}= & \left(\eta_{20}+\eta_{02}\right)^{2}+4 \eta_{11}^{2} \\
\varphi_{3}= & \left(\eta_{30}-3 \eta_{12}\right)^{2}+\left(3 \eta_{21}-\eta_{03}\right)^{2} \\
\varphi_{4}= & \left(\eta_{30}+\eta_{12}\right)^{2}+\left(\eta_{21}+\eta_{03}\right)^{2} \\
\varphi_{5}= & \left(\eta_{30}-3 \eta_{12}\right)\left(\eta_{30}+\eta_{12}\right)\left\{\left(\eta_{30}+\eta_{12}\right)^{2}-3\left(\eta_{21}+\eta_{03}\right)^{2}\right\}+ \\
& \left(3 \eta_{21}-\eta_{03}\right)\left(\eta_{21}+\eta_{03}\right)\left\{3\left(\eta_{30}+\eta_{12}\right)^{2}-\left(\eta_{21}+\eta_{03}\right)^{2}\right\} \\
\varphi_{6}= & \left(\eta_{20}-\eta_{02}\right)\left\{\left(\eta_{30}+\eta_{12}\right)^{2}-\left(\eta_{21}+\eta_{03}\right)^{2}\right\}+4 \eta_{11}\left(\eta_{30}+\eta_{12}\right)\left(\eta_{21}+\eta_{03}\right) \\
\varphi_{7}= & \left(3 \eta_{21}-\eta_{30}\right)\left(\eta_{30}+\eta_{12}\right)\left\{\left(\eta_{30}+\eta_{12}\right)^{2}-3\left(\eta_{21}+\eta_{03}\right)^{2}\right\}+ \\
& \left(3 \eta_{21}-\eta_{03}\right)\left(\eta_{21}+\eta_{03}\right)\left\{3\left(\eta_{30}+\eta_{12}\right)^{2}-\left(\eta_{21}+\eta_{03}\right)^{2}\right\}
\end{aligned}
$$

The total of 142 images collection shape feature extraction using $\mathrm{Hu}$ Moment Invariants produce of $142 \times 7$ shape feature metric.

Tabel 3. Table of Shape Feature by the extraction using Hu Moments

\begin{tabular}{|l|c|c|c|c|}
\hline \multicolumn{1}{|c|}{$\boldsymbol{I D}$} & $\boldsymbol{h 1}$ & $\boldsymbol{h} \boldsymbol{1}$ & $\boldsymbol{h} \ldots$ & $\boldsymbol{h}$ \\
\hline Imgl & $\ldots$ & $\ldots$ & $\ldots$ & $\ldots$ \\
\hline Img2 & $\ldots$ & $\ldots$ & $\ldots$ & $\ldots$ \\
\hline Img... & $\ldots$ & $\ldots$ & $\ldots$ & $\ldots$ \\
\hline Imgn & $\ldots$ & $\ldots$ & $\ldots$ & $\ldots$ \\
\hline
\end{tabular}

\subsection{Multiplication Metric}

Multiplication Metric/ Metric Processing is a process of inner-product multiplication metric between metadata feature of impressions, colors and shape. Multiplication impression feature metric with Color feature metric produce Impression-Color metric[2], while the impressions feature metric with shape feature metric produce Impression-Shape Metric. 


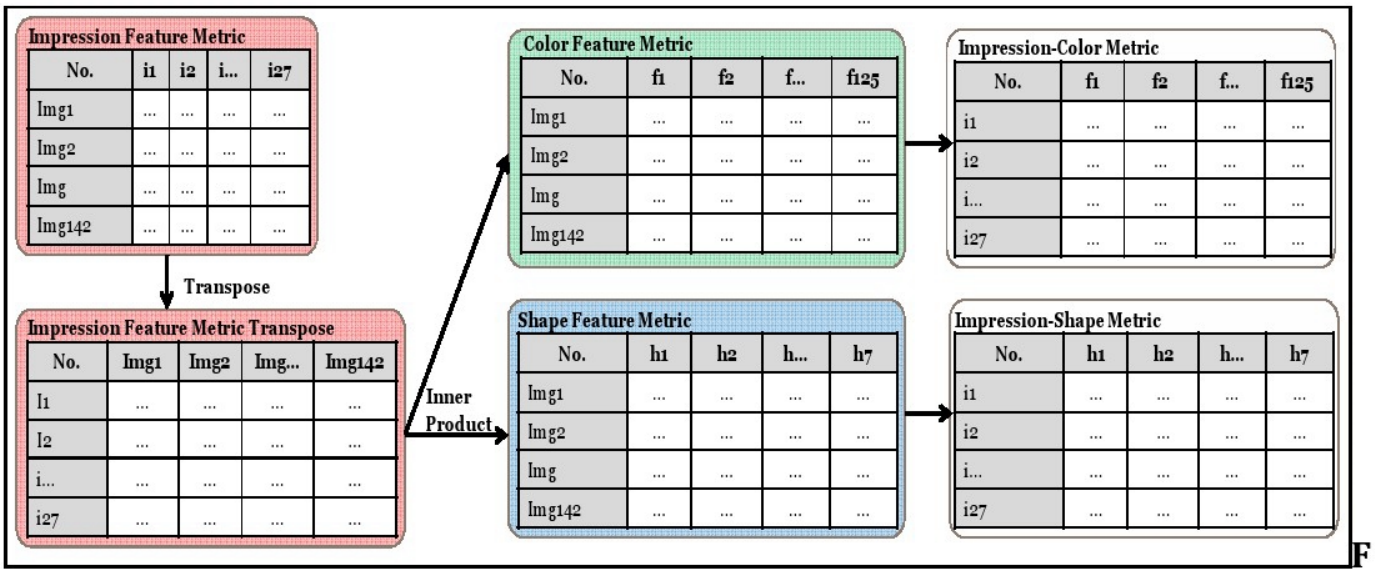

igure 7. Multiplication Metrics process, Impression metric with Color metric produce Impression-Color metric, Impression metric with Shape metric produce Impression-Shape metric

\subsection{Query Impression/Image}

Query image or impressions that entered by the user is used to perform a search and get the similar information to the system. Query image is obtained from an existing image in the smartphone or taken using a smartphone camera. Query image will be extraction feature using histogram 3D-CVQ and Hu Moment to get the metadata that will be used to measure the similarity with songket dataset, and displays the results of impressions (Figure 8.a). Impression Query is a word that is selected by the user from list impression to getting metadata of impression-color metric and impression shape metric, and then performed similarity measurement process with metadata color and shape metric on dataset, and display the results of images (Figure 8.b).

a)

a)
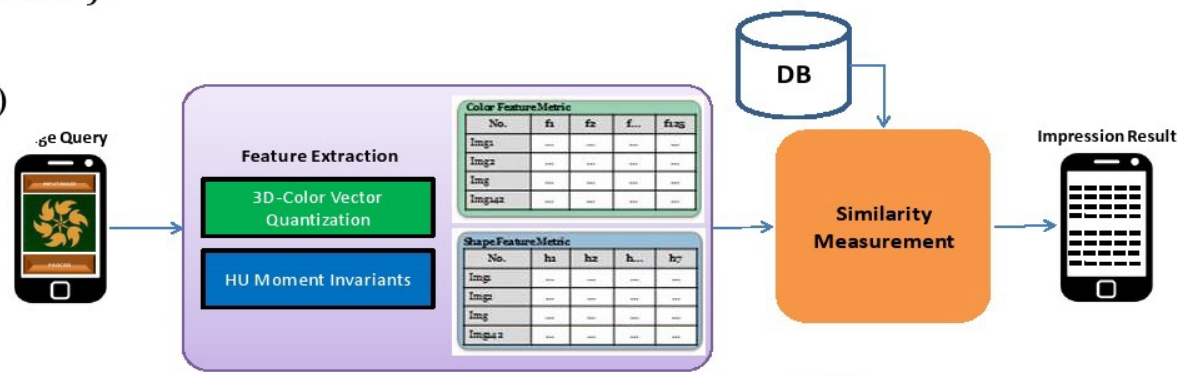

b)

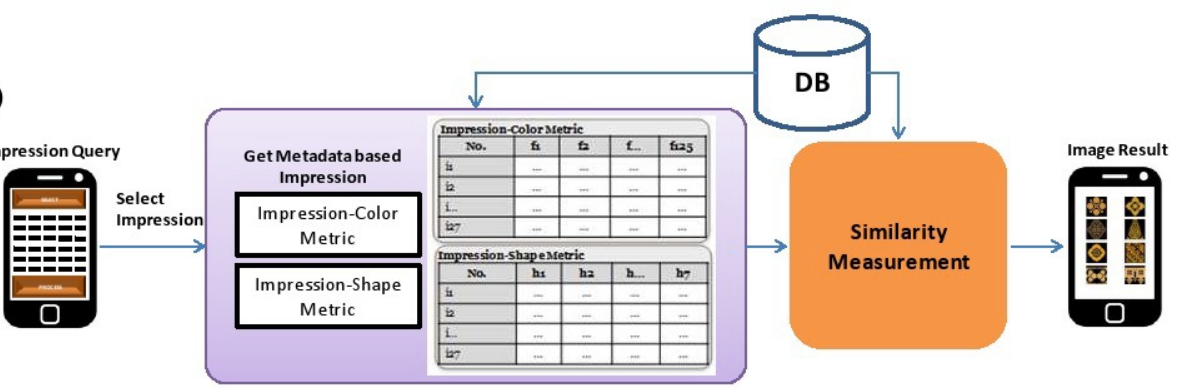

Figure 8. Query Process of Image and Impression Retrieval System, a) Image as Query for displays the results of impressions, b) Impression as Query Process for displays the results of Images 


\subsection{Similarity Measurement}

Similarity measurment method is used to measure the similarity between the impression or image queries that inputed by the user. Cosine method[5] used for measure the similarity between image query or impression query with the metadata on datasets, and measure based color and shape feature. The formula of Cousine method is shown at equation 15.

$$
\text { Cosine }=\frac{\sum_{\mathrm{i=1}}^{\mathrm{n}} \mathrm{A}_{\mathrm{i}} \times \mathrm{B}_{\mathrm{i}}}{\sqrt{\sum_{\mathrm{i}=1}^{\mathrm{n}}\left(\mathrm{A}_{\mathrm{i}}\right)^{2}} \times \sqrt{\sum_{\mathrm{i}=1}^{\mathrm{n}}\left(\mathrm{B}_{\mathrm{i}}\right)^{2}}}
$$

Where $\mathrm{n}$ is the metadata on datasets, $\mathrm{A}$ is metadata on image and impression query, B is metadata on datasets. Besides similarity measuring based of colors and shapes, we also conducted an experiment by combining colors and shapes, also called aggregation. In this experiment, we use an image as a query and perform the measurement process based on color and shape using cousine methods and displays the results of 10 impressions. If we found the same impression (between measurements based on color and shape), then combine the value (summation), furthermore repeated sorting the value from the highest to lowest, the last taken 10 highest score and show impressions. Aggregation is used in the experiment of impression as the query.

\section{Experiment and Analysis}

In this experiment, we have to analyze the performance based color, shape and aggregation color-shape feature. First, experiment use multiimpression as a query. We have to carry out a process of similarity measurements based on color, shape and aggregation color-shape between the value of impression as query with metric color and shape in dataset, and then display the results of image variations songket motifs. Second, experiments use songket image as a query, where the images are extracted using 3D-CVQ and HU Moments, then measuring the similarity between the results of extracted of query image with impression-color and impression shape metrics that stored in the database, and displays the results of impressions.

This experiment carried out by using 10 different queries, each test displays 10 results. Any result that displayed and calculated similarity based on the value closest to the query.

\subsection{Impression Query}

\subsubsection{Rules of Calculation for Impression Query}

To calculate the similarity by using the impression as a query use the formula as in eq. 17 , the similarity calculation as follows :

$$
\left\{\begin{array}{l}
s c r_{i}=10-i+1 \leftarrow \mathrm{cr}_{1}=\mathrm{cq} \\
s c r_{i}=0 \leftarrow \text { otherwise }
\end{array}\right.
$$


Score $=\sum_{i=1}^{10} s r_{1}$

Where, $\mathrm{cr}$ is a displayed image, where in each image include the impression has been compiled in a database. cq is a category of impressions query, and scr are any image displayed that have similar impression with the impression query.

In this experiment, each experiment displays 10 images. Each image have an impression. If the impression of the image that appears similar with impression in the query rated a true or value of 1 , and if not rated a false or value of 0 , likewise as on the next image, until to sequence of 10 images. The provision furthermore, to the order of the first image given a score of 10 , the second image order were given a score of 9, and next until the image sequence to 10 given a score of 1 , the overall total score was 55 . Finally, the value of True or False statements multiplied by scores from the sequence of images, and counted the total score of true. There are complete explanation as in the table as follows :

Table 4. The example of Calculation the degree of similarity between the impression query with impression contained on the displayed image.

\begin{tabular}{|c|c|c|c|c|c|c|c|c|c|c|c|}
\hline \multicolumn{12}{|c|}{$\begin{array}{c}\text { Impression Query : } \\
\text { Keberanian, Kewibawaan, Persaudaraan }\end{array}$} \\
\hline \multicolumn{12}{|c|}{ Image retrieved } \\
\hline \multicolumn{4}{|c|}{ Based Color } & \multicolumn{4}{|c|}{ Based Shape } & \multicolumn{4}{|c|}{ Aggregation (Color and Shape) } \\
\hline $\begin{array}{c}\text { Image } \\
\text { ID }\end{array}$ & $\mathbf{T} / \mathbf{F}$ & Score & $\begin{array}{c}\text { Score } \\
\text { (T) }\end{array}$ & $\begin{array}{c}\text { Image } \\
\text { ID }\end{array}$ & $\mathbf{T} / \mathbf{F}$ & Score & $\begin{array}{c}\begin{array}{c}\text { Score } \\
\text { (T) }\end{array} \\
\end{array}$ & $\begin{array}{c}\text { Image } \\
\text { ID }\end{array}$ & $\mathrm{T} / \mathrm{F}$ & Score & $\begin{array}{c}\text { Score } \\
\text { (T) }\end{array}$ \\
\hline i36 & 1 & 10 & 10 & i72 & 1 & 10 & 10 & i72 & 1 & 10 & 10 \\
\hline i94 & 1 & 9 & 9 & i101 & 0 & 9 & 0 & i101 & 0 & 9 & 0 \\
\hline i99 & 1 & 8 & 8 & i61 & 0 & 8 & 0 & i61 & 0 & 8 & 0 \\
\hline i127 & 1 & 7 & 7 & i47 & 1 & 7 & 7 & i47 & 1 & 7 & 7 \\
\hline i63 & 1 & 6 & 6 & i14 & 1 & 6 & 6 & i14 & 1 & 6 & 6 \\
\hline i120 & 1 & 5 & 5 & i27 & 0 & 5 & 0 & i27 & 0 & 5 & 0 \\
\hline i84 & 1 & 4 & 4 & i19 & 0 & 4 & 0 & i19 & 0 & 4 & 0 \\
\hline i132 & 1 & 3 & 3 & i25 & 1 & 3 & 3 & i25 & 1 & 3 & 3 \\
\hline i79 & 1 & 2 & 2 & i15 & 1 & 2 & 2 & i15 & 1 & 2 & 2 \\
\hline i87 & 0 & 1 & 0 & i77 & 0 & 1 & 0 & i77 & 0 & 1 & 0 \\
\hline \multicolumn{2}{|c|}{ TT : 9} & \multicolumn{2}{|c|}{ TSc.T : 54} & \multicolumn{2}{|c|}{ TT $: 5$} & \multicolumn{2}{|c|}{ TSc.T : 28} & \multicolumn{2}{|c|}{ TT : 5} & \multicolumn{2}{|c|}{ TSc.T : 28} \\
\hline
\end{tabular}

TT : Total True, TSc. T : Total Score True

Where Image ID is image display from similarity measurement process, each image has an impression. In this experiment the results displayed image should exhibit similarities impression by impression query. 


\subsubsection{Experiments with Impression Query}

In this experiment use multi-impression query or more than one impression. This experiment display 10 image based color and display 10 images based shape, that have the similarity impression with the multi-query impression. Experiment conducted to determine the performance between query impression with displayed image results that contained of impressions. In Table 5, we can see the results of the experiment as follows.

Table 5. Experiment using impressions query and calculate the level of similarity between query Impressions with impressions contained in images are displayed.

\begin{tabular}{|c|c|c|c|c|c|c|c|}
\hline \multirow{2}{*}{$\begin{array}{l}\text { No. } \\
\text { Exp }\end{array}$} & \multirow{2}{*}{ Query Impression } & \multicolumn{2}{|c|}{$\begin{array}{c}\text { Retrieved } \\
\text { Based Color }\end{array}$} & \multicolumn{2}{|c|}{$\begin{array}{c}\text { Retrieved } \\
\text { Based Shape }\end{array}$} & \multicolumn{2}{|c|}{$\begin{array}{c}\text { Aggregation } \\
\text { (Color and Shape) }\end{array}$} \\
\hline & & $\begin{array}{l}\text { Total } \\
\text { True }\end{array}$ & $\begin{array}{c}\text { Total Score } \\
\text { True }\end{array}$ & $\begin{array}{l}\text { Total } \\
\text { True }\end{array}$ & \begin{tabular}{|c|}
$\begin{array}{c}\text { Total Score } \\
\text { True }\end{array}$ \\
\end{tabular} & $\begin{array}{l}\text { Total } \\
\text { True }\end{array}$ & $\begin{array}{c}\text { Total } \\
\text { Score True }\end{array}$ \\
\hline 1 & $\begin{array}{l}\text { Keberanian } \\
\text { Kewibawaan } \\
\text { Persaudaraan }\end{array}$ & 9 & 54 & 5 & 28 & 5 & 28 \\
\hline 2 & $\begin{array}{l}\text { Kesetian } \\
\text { Kemakmuran } \\
\text { Kedamaian } \\
\end{array}$ & 6 & 34 & 4 & 24 & 4 & 24 \\
\hline 3 & $\begin{array}{l}\text { Keberanian } \\
\text { Bangsawan } \\
\text { Kasih_Sayang }\end{array}$ & 8 & 44 & 1 & 9 & 1 & 10 \\
\hline 4 & $\begin{array}{l}\text { Berhati_Mulia } \\
\text { Persaudaraan } \\
\text { Ketulusan } \\
\text { Rendah_Hati }\end{array}$ & 9 & 50 & 3 & 8 & 3 & 14 \\
\hline 5 & $\begin{array}{l}\text { Keberanian } \\
\text { Kepahlawanan } \\
\text { Kewibawaan }\end{array}$ & 8 & 47 & 2 & 11 & 2 & 11 \\
\hline 6 & $\begin{array}{l}\text { Kesuburan } \\
\text { Kebahagiaan } \\
\text { Tahu Diri } \\
\end{array}$ & 9 & 50 & 4 & 22 & 4 & 22 \\
\hline 7 & $\begin{array}{l}\text { Kesucian } \\
\text { Kesejahteraan } \\
\text { Amanah }\end{array}$ & 6 & 42 & 2 & 12 & 2 & 12 \\
\hline 8 & $\begin{array}{l}\text { Kerukunan } \\
\text { Saling Menghormati } \\
\text { Bijaksana } \\
\text { Cerdik_Pandai } \\
\end{array}$ & 7 & 43 & 3 & 21 & 3 & 21 \\
\hline 9 & $\begin{array}{l}\text { Kesucian } \\
\text { Tenggang_Rasa } \\
\text { Ketaqwaan }\end{array}$ & 6 & 29 & 1 & 2 & 1 & 2 \\
\hline 10 & $\begin{array}{l}\text { Kedamaian } \\
\text { Kerukunan } \\
\text { Bijaksana }\end{array}$ & 5 & 26 & 5 & 27 & 5 & 30 \\
\hline & Average : & 7.3 & 41.9 & 3 & 16.4 & 3 & 17.4 \\
\hline
\end{tabular}

Experiments of image search by the using impressions as queries and based color features can be known by the true value average is 7.3 of the 10 image displayed on each experiments, and the average calculation of the total score true is 41.9 by 55 total scores on each experiments. While based shape features can be known by the true value average is 3 of the 10 image displayed on each experiments, and the average calculation of the total score 
true was 16.4 of the 55 total scores on each experiments. Furthermore, based aggregation color and shape features can be known by the true value average is 3 of the 10 image displayed on each experiments, and the average calculation of the total score true was 17.4 of the 55 total scores on each experiments

\subsection{Image Query}

\subsubsection{The Rules of Calculation Precision for Image Query}

The rules of calculation precision to analyze the precision between image query with the generated impression. Comparison with comparing Impression retrieved with impression that contained on query image. The way to present precision defined in equation 18.

$$
\text { Precision }=\frac{\begin{array}{c}
\text { Total Number similar impressions retrieved with } \\
\text { impression on query image }
\end{array}}{\text { Total Number of Impression contained in image query }} \times 100
$$

\subsubsection{Experiments Query Image}

This experiment use Image Query and displaying 10 impressions based on color, shape and aggregation color-shape feature the similar with impressions that contained on image query. Experiment conducted to

\begin{tabular}{|c|c|c|c|c|c|}
\hline \multirow{2}{*}{$\begin{array}{l}\text { No. } \\
\text { Exp }\end{array}$} & \multirow{2}{*}{\multicolumn{2}{|c|}{ Image Query \& his Impressions }} & \multicolumn{3}{|c|}{ Impression Retrieved } \\
\hline & & & Based Color & Based Shape & $\begin{array}{c}\text { Aggregation } \\
\text { (Color \& Shape) }\end{array}$ \\
\hline 1 & $\mid \begin{array}{l}9 \\
10 \\
0\end{array}$ & $\begin{array}{l}\text { Berhati_Mulia } \\
\text { Kerukunan } \\
\text { Tenggang_Rasa }\end{array}$ & $\begin{array}{c}\text { Gotong_Royong } \\
\text { Berhati_Mulia } \\
\text { Kerukunan } \\
\text { Murah_Rezeki } \\
\text { Rendah_Hati } \\
\text { Saling_Menghormati } \\
\text { Tahu Diri } \\
\text { Tenggang_Rasa } \\
\text { Ketaqwaan } \\
\text { Kesuburan } \\
\end{array}$ & $\begin{array}{c}\text { Kepahlawanan } \\
\text { Murah_Rezeki } \\
\text { Kesuburan } \\
\text { Persaudaraan } \\
\text { Kerukunan } \\
\text { Kemakmuran } \\
\text { Berhati_Mulia } \\
\text { Saling_Menghormati } \\
\text { Kedamaian } \\
\text { Kesejahteraan } \\
\end{array}$ & $\begin{array}{c}\text { Berhati_Mulia } \\
\text { Kerukunan } \\
\text { Kepahlawanan } \\
\text { Murah_Rezeki } \\
\text { Kesuburan } \\
\text { Persaudaraan } \\
\text { Kemakmuran } \\
\text { Saling_Menghormati } \\
\text { Kedamaian } \\
\text { Kesejahteraan } \\
\end{array}$ \\
\hline & & Precision (\%) : & 100 & 66.6 & 66.6 \\
\hline 2 & है & $\begin{array}{l}\text { Bangsawan } \\
\text { Murah_Rezeki } \\
\text { Sejahtera }\end{array}$ & $\begin{array}{c}\text { Bangsawan } \\
\text { Murah_Rezeki } \\
\text { Kewibawaan } \\
\text { Sopan_Santun } \\
\text { Kesejahteraan } \\
\text { Tenggang_Rasa } \\
\text { Rendah_Hati } \\
\text { Bijaksana } \\
\text { Ketaqwaan } \\
\text { Saling_Menghormati }\end{array}$ & $\begin{array}{c}\text { Kewibawaan } \\
\text { Bangsawan } \\
\text { Kerukunan } \\
\text { Ketulusan } \\
\text { Rendah_Hati } \\
\text { Cerdik_Pandai } \\
\text { Saling_Menghormati } \\
\text { Kepahlawanan } \\
\text { Sopan_Santun } \\
\text { Kesetiaan } \\
\end{array}$ & $\begin{array}{c}\text { Bangsawan } \\
\text { Kewibawaan } \\
\text { Murah_Rezeki } \\
\text { Kewibawaan } \\
\text { Kerukunan } \\
\text { Ketulusan } \\
\text { Rendah_Hati } \\
\text { Cerdik_Pandai } \\
\text { Saling_Menghormati } \\
\text { Sopan_Santun } \\
\end{array}$ \\
\hline & & Precision (\%) : & 100 & 33.3 & 66.6 \\
\hline
\end{tabular}
determine the performance of the query image with the results displayed of impressions. In Table 6 we can see the experiment.

Table 6. Experiment using image as query and calculate precision between

impression that contained in image query with impressions retrieved. 


\begin{tabular}{|c|c|c|c|c|}
\hline 3 & $\begin{array}{l}\text { Kepahlawanan } \\
\text { Saling_Menghormati } \\
\text { Tahu_Diri }\end{array}$ & $\begin{array}{c}\text { Ketaqwaan } \\
\text { Kepahlawanan } \\
\text { Kesejahteraan } \\
\text { Cerdik_Pandai } \\
\text { Tahu Diri } \\
\text { Tenggang_Rasa } \\
\text { Kedamaian } \\
\text { Keberanian } \\
\text { Saling_Menghormati } \\
\text { Murah_Rezeki } \\
\end{array}$ & $\begin{array}{l}\text { Gotong_Royong } \\
\text { Kedamaian } \\
\text { Kesejahteraan } \\
\text { Kebahagian } \\
\text { Berhati_Mulia } \\
\text { Kepahlawanan } \\
\text { Murah_Rezeki } \\
\text { Kesuburan } \\
\text { Kemakmuran } \\
\text { Persaudaraan } \\
\end{array}$ & $\begin{array}{c}\text { Kepahlawanan } \\
\text { Gotong_Royong } \\
\text { Kedamaian } \\
\text { Kesejahteraan } \\
\text { Kebahagian } \\
\text { Berhati_Mulia } \\
\text { Murah_Rezeki } \\
\text { Kesuburan } \\
\text { Kemakmuran } \\
\text { Persaudaraan } \\
\end{array}$ \\
\hline \multicolumn{2}{|r|}{ Precision (\%) : } & 100 & 33.3 & 33.3 \\
\hline 4 & $\begin{array}{l}\text { Kesuburan } \\
\text { Saling_Menghormati }\end{array}$ & $\begin{array}{c}\text { Gotong_Royong } \\
\text { Berhati_Mulia } \\
\text { Kerukunan } \\
\text { Rendah_Hati } \\
\text { Murah_Rezeki } \\
\text { Saling_Menghormati } \\
\text { Tahu Diri } \\
\text { Sopan_Santun } \\
\text { Tenggang_Rasa } \\
\text { Ketaqwaan } \\
\end{array}$ & $\begin{array}{c}\text { Ketulusan } \\
\text { Amanah } \\
\text { Sopan_Santun } \\
\text { Rendah_Hati } \\
\text { Kesetiaan } \\
\text { Kesucian } \\
\text { Kerukunan } \\
\text { Cerdik_Pandai } \\
\text { Saling_Menghormati } \\
\text { Kesuburan } \\
\end{array}$ & $\begin{array}{c}\text { Saling_Menghormati } \\
\text { Ketulusan } \\
\text { Amanah } \\
\text { Sopan_Santun } \\
\text { Rendah_Hati } \\
\text { Kesetiaan } \\
\text { Kesucian } \\
\text { Gotong_Royong } \\
\text { Kerukunan } \\
\text { Cerdik_Pandai } \\
\end{array}$ \\
\hline \multicolumn{2}{|r|}{ Precision (\%) : } & 50 & 100 & 50 \\
\hline 5 & $\begin{array}{l}\text { Keberanian } \\
\text { Tahu_Diri }\end{array}$ & $\begin{array}{c}\text { Keberanian } \\
\text { Kesetiaan } \\
\text { Tahu Diri } \\
\text { Amanah } \\
\text { Rendah_Hati } \\
\text { Cerdik_Pandai } \\
\text { Bijaksana } \\
\text { Saling_Menghormati } \\
\text { Ketulusan } \\
\text { Kesejahteraan } \\
\end{array}$ & $\begin{array}{c}\text { Kerukunan } \\
\text { Kepahlawanan } \\
\text { Saling_Menghormati } \\
\text { Persaudaraan } \\
\text { Kesuburan } \\
\text { Berhati_Mulia } \\
\text { Murah_Rezeki } \\
\text { Kemakmuran } \\
\text { Kesejahteraan } \\
\text { Kedamaian } \\
\end{array}$ & $\begin{array}{c}\text { Kerukunan } \\
\text { Kepahlawanan } \\
\text { Saling_Menghormati } \\
\text { Persaudaraan } \\
\text { Kesuburan } \\
\text { Berhati_Mulia } \\
\text { Murah_Rezeki } \\
\text { Kemakmuran } \\
\text { Keberanian } \\
\text { Kesetiaan } \\
\end{array}$ \\
\hline \multicolumn{2}{|r|}{ Precision (\%) : } & 100 & 0 & 50 \\
\hline 6 & $\begin{array}{l}\text { Kebahagian } \\
\text { Ketaqwaan } \\
\text { Sopan Santun }\end{array}$ & $\begin{array}{c}\text { Kebahagian } \\
\text { Ketaqwaan } \\
\text { Sopan_Santun } \\
\text { Murah_Rezeki } \\
\text { Kerukunan } \\
\text { Kedamaian } \\
\text { Ketulusan } \\
\text { Tenggang_Rasa } \\
\text { Rendah_Hati } \\
\text { Persaudaraan } \\
\end{array}$ & $\begin{array}{c}\text { Kewibawaan } \\
\text { Kerukunan } \\
\text { Kepahlawanan } \\
\text { Gotong_Royong } \\
\text { Bangsawan } \\
\text { Saling_Menghormati } \\
\text { Kesuburan } \\
\text { Berhati_Mulia } \\
\text { Kedamaian } \\
\text { Kesejahteraan } \\
\end{array}$ & $\begin{array}{c}\text { Kewibawaan } \\
\text { Kebahagian } \\
\text { Kerukunan } \\
\text { Kepahlawanan } \\
\text { Ketaqwaan } \\
\text { Gotong_Royong } \\
\text { Sopan_Santun } \\
\text { Bangsawan } \\
\text { Saling_Menghormati } \\
\text { Kesuburan } \\
\end{array}$ \\
\hline \multicolumn{2}{|r|}{ Precision (\%) : } & 100 & 0 & 100 \\
\hline 7 & $\begin{array}{l}\text { Kemakmuran } \\
\text { Tahu Diri } \\
\text { Sopan Santun }\end{array}$ & $\begin{array}{c}\text { Tahu Diri } \\
\text { Kemakmuran } \\
\text { Sopan_Santun } \\
\text { Kesejahteraan } \\
\text { Saling_Menghormati } \\
\text { Bijaksana } \\
\text { Kasih_Sayang } \\
\text { Amanah } \\
\text { Kewibawaan } \\
\text { Kerukunan } \\
\end{array}$ & $\begin{array}{c}\text { Cerdik_Pandai } \\
\text { Kewibawaan } \\
\text { Rendah_Hati } \\
\text { Sopan_Santun } \\
\text { Amanah } \\
\text { Ketaqwaan } \\
\text { Kerukunan } \\
\text { Ketulusan } \\
\text { Kesucian } \\
\text { Kesetiaan } \\
\end{array}$ & $\begin{array}{c}\text { Cerdik_Pandai } \\
\text { Sopan_Santun } \\
\text { Kewibawaan } \\
\text { Rendah_Hati } \\
\text { Amanah } \\
\text { Ketaqwaan } \\
\text { Tahu Diri } \\
\text { Kemakmuran } \\
\text { Kerukunan } \\
\text { Ketulusan } \\
\end{array}$ \\
\hline & Precision (\%) : & 100 & 33.3 & 100 \\
\hline
\end{tabular}




\begin{tabular}{|c|c|c|c|c|}
\hline 8 & $\begin{array}{l}\text { Kesuburan } \\
\text { Tahu Diri } \\
\text { Cerdik Pandai }\end{array}$ & $\begin{array}{c}\text { Kesuburan } \\
\text { Kemakmuran } \\
\text { Cerdik_Pandai } \\
\text { Murah_Rezeki } \\
\text { Amanah } \\
\text { Kerukunan } \\
\text { Tahu Diri } \\
\text { Sopan_Santun } \\
\text { Kasih_Sayang } \\
\text { Ketulusan } \\
\end{array}$ & $\begin{array}{c}\text { Amanah } \\
\text { Kesucian } \\
\text { Sopan_Santun } \\
\text { Rendah_Hati } \\
\text { Kesetiaan } \\
\text { Ketulusan } \\
\text { Cerdik_Pandai } \\
\text { Kerukunan } \\
\text { Ketaqwaan } \\
\text { Kesuburan } \\
\end{array}$ & $\begin{array}{c}\text { Kesuburan } \\
\text { Cerdik_Pandai } \\
\text { Amanah } \\
\text { Kesucian } \\
\text { Sopan_Santun } \\
\text { Rendah_Hati } \\
\text { Kesetiaan } \\
\text { Ketulusan } \\
\text { Kerukunan } \\
\text { Ketaqwaan } \\
\end{array}$ \\
\hline & Precision (\%) : & 100 & 66.6 & 66,6 \\
\hline 9 & $\begin{array}{l}\text { Kebahagian } \\
\text { Tahu Diri } \\
\text { Cerdik Pandai }\end{array}$ & $\begin{array}{c}\text { Kebahagian } \\
\text { Ketaqwaan } \\
\text { Bijaksana } \\
\text { Tahu Diri } \\
\text { Ketulusan } \\
\text { Kesejahteraan } \\
\text { Cerdik_Pandai } \\
\text { Saling_Menghormati } \\
\text { Tenggang_Rasa } \\
\text { Kedamaian } \\
\end{array}$ & $\begin{array}{c}\text { Cerdik_Pandai } \\
\text { Kewibawaan } \\
\text { Rendah_Hati } \\
\text { Sopan_Santun } \\
\text { Ketaqwaan } \\
\text { Amanah } \\
\text { Kerukunan } \\
\text { Ketulusan } \\
\text { Saling_Menghormati } \\
\text { Kasih_Sayang } \\
\end{array}$ & $\begin{array}{c}\text { Cerdik_Pandai } \\
\text { Kewibawaan } \\
\text { Kebahagian } \\
\text { Rendah_Hati } \\
\text { Ketaqwaan } \\
\text { Bijaksana } \\
\text { Sopan_Santun } \\
\text { Tahu Diri } \\
\text { Ketulusan } \\
\text { Kesejahteraan } \\
\end{array}$ \\
\hline & Precision (\%) : & 100 & 33.3 & 100 \\
\hline 10 & $\begin{array}{l}\text { Keberanian } \\
\text { Sopan Santun } \\
\text { Rendah Hati }\end{array}$ & $\begin{array}{c}\text { Kesetiaan } \\
\text { Keberanian } \\
\text { Kasih_Sayang } \\
\text { Tahu Diri } \\
\text { Rendah_Hati } \\
\text { Cerdik_Pandai } \\
\text { Ketulusan } \\
\text { Sopan_Santun } \\
\text { Amanah } \\
\text { Saling_Menghormati } \\
\end{array}$ & $\begin{array}{c}\text { Cerdik_Pandai } \\
\text { Kewibawaan } \\
\text { Rendah_Hati } \\
\text { Sopan_Santun } \\
\text { Amanah } \\
\text { Ketaqwaan } \\
\text { Kerukunan } \\
\text { Ketulusan } \\
\text { Saling_Menghormati } \\
\text { Kasih_Sayang } \\
\end{array}$ & $\begin{array}{c}\text { Rendah_Hati } \\
\text { Sopan_Santun } \\
\text { Kesetiaan } \\
\text { Keberanian } \\
\text { Cerdik_Pandai } \\
\text { Kewibawaan } \\
\text { Kasih_Sayang } \\
\text { Tahu Diri } \\
\text { Cerdik_Pandai } \\
\text { Ketulusan } \\
\end{array}$ \\
\hline & Precision (\%) : & 100 & 66.7 & 100 \\
\hline \multicolumn{2}{|c|}{ Total Average (\%) : } & 95 & 43.3 & 73.3 \\
\hline
\end{tabular}

Experiments of impression search by the using Image as queries, experiments based color features can be known the average precision $95 \%$, experiments based shape features can be known the average precision $43.3 \%$, and experiments based aggregation color and shape features can be known the average precision $73.3 \%$.

\section{CONCLUSION}

This research proposed a new system with a new approach for semantic songket image retrieval based on feature extraction with impression. We use 142 Songket image from Riau, and for each motifs has different philosophy and in the form of rhyme. With 3D-Color Vector Quantization and $\mathrm{Hu}$ Moment invariant method to get metadata color features metric and shape features metric, and to get metadata impression feature metric. We do this research with the leader of the local culture for understanding philosophy of the rhyme in each of songket motifs. Then, it converts to impression for understood the public, and color meaning based local cultural beliefs that contained in each songket image. 
The experiment to analyze the performance based color, shape and aggregation color-shape feature. Based on 10 experiment using impression query, 1) Results based Color, we found the average value of True 7.3 (out of 10 ) and the total score of 41.9 (out of a maximum value of 55) of the 10 images are displayed in each experiment, 2) Results based Shape, we found the average value of True 3 (out of 10) and the total score of 16.4, 3) Based Aggregation color and shape, we found the average value of True 3 (out of 10 ) and the total score of 17.4 (out of a maximum value of 55) of the 10 images are displayed. While based on 10 experiment using Image query, 1) Results based Color, we found the average precision 95\% of the 10 Impression are displayed in each experiment, 2) Results based Shape, we found the average precision 43.3\%, 3) Based Aggregation color and shape, we found the average precision $73.3 \%$.

From our experiments, it can be concluded that the best search system that use query impression is based on the color, the average value of True 7.3 and the total score of 41.9 , of the 10 image are displayed in each experiment. While using image query is based on the color with the average precision of $95 \%$ of the 10 Impression are displayed in each experiment.

\section{REFERENCES}

[1] Amirullah, Desi, Ali Ridho Barakbah, Achmad Basuki, Semantic Songket Image Search with Impression based Feature Extraction, The Fourth Indonesian-Japanese Conference, Knowledge Creation Intelegence Computing, , Surabaya, Indonesia, March 24-26, 2015.

[2] Kuswara, Devira Nanda, Ali Ridho Barakbah, Nur Rosyid M, Yuliana Setiowati, Impression Generation of Indonesian Cultural Paintings for Mobile Aplication with Culture Dependent Color-Impression Metric Creation Content, Emitter Journal of Enginering Technology, Vol. 2 No.1, June, 2014.

[3] Ali Ridho Barakbah, Yasushi Kiyoki, 3D-Color Vector Quantization for Image Retrieval Systems, International Database Forum (iDB) 2008, Izaka, Japan, September 21-23, 2008.

[4] Chary, R. VenkataRemana, Dr. D. Rayja Laksmhi, Dr. K.V.N. Sunitha., Feature Extraction Method For Color Image Similarity, ACIJ, India, 2012.

[5] Nugrowati, Ayuninda Dwi., Ali Ridho Barakbah, Nana Ramadijanti, Yuliana Setyowati. Batik Image Search System with Extracted Combination of Color and Shape Feature, International Conference on imaging and printing technologies, Bangkok, Thailand, November 5-7, 2014.

[6] Flusser, Jan. , Tomas Suk, Barbara Zitova. Moment and Moment Invarian in Pattern Recognition, 2009, Prague, Czech Republic

[7] Malik, Abdul., Tenas Effendy, Hasan Yunus, Auzar Thaher, Corak Ragi dan Tenun Melayu Riau, Balai Kajian dan Pengembangan Budaya Melayu, 2004, AdiCita, Yogyakarta 
[8] Suryani, Indah Yudi, Ali Ridho Barakbah, Entin Martiana Kusumanigtyas, A Semantic Multi-Query Image Search System with Analytical Function for Representative Query Color Generation, The First Indonesian-Japanese Conference, Knowledge Creation Intelegence Computing, Surabaya, Indonesia, March 13-14, 2012.

[9] Theodiridis, Sergios., Konstantinos Koutroumbas, Pattern Recognition Fourth Edition, Elsevier, inc., 2009, Academic Press is an imprint od Elsevier, Burlington, MA 01803, USA., California 92101-4495, USA., London WCIX 8RR, UK 